Analitika: Jurnal Magister Psikologi UMA, Vol. 13 (2) Desember (2021)

ISSN: 2085-6601 (Print), ISSN: 2502-4590 (Online)

DOI: : http://doi.org/10.31289/analitika.v13i1.5943

\author{
ANALITIKA \\ Jurnal Magister Psikologi UMA
}

Available online http://ojs.uma.ac.id/index.php/analitika

\title{
Rasa Syukur Pekerja Harian Sektor Pariwisata pada Masa Pandemi Covid-19
}

\section{Daily Workers Gratitude in The Tourism Sector during The Covid-19 Pandemic}

\author{
Debi Angelina Br Barus* \& Epifania Margareta Ladapase \\ Program Studi Psikologi, Fakultas Ilmu-Ilmu Sosial, Universitas Nusa Nipa, Indonesia
}

Diterima: 15 Oktober 2021, disetujui: 23 Desember 2021, dipublish: 30 Desember 2021

*Corresponding author: E-mail: debibarusok@gmail.com

\begin{abstract}
Abstrak
Tujuan dari penelitian ini untuk mengetahui gambaran rasa syukur pekerja harian sektor pariwisata pada masa pandemi Covid-19. Penelitian ini menggunakan metode penelitian kualitatif deskriptif dengan teknik pengambilan subjek penelitian menggunakan snowball. Jumlah subjek penelitian sebanyak empat orang yang berprofesi sebagai tour guide dan supir travel. Pengumpulan data dalam penelitian ini dilakukan dengan teknik wawancara, observasi, dan dokumentasi. Dari hasil penelitian ditemukan bahwa rasa syukur yang dimiliki oleh pekerja harian sektor pariwisata, baik secara transpersonal maupun personal, bersumber dari spritual dan dukungan teman seprofesi sehingga mampu bertahan menjalankan hidup pada masa pandemi Covid-19. Ungkapan rasa syukur pekerja harian sektor pariwisata pada masa pandemi Covid-19 tampak melalui penghargaan atas penghasilan yang mereka peroleh setiap hari, serta perasaan positif seperti bahagia dan menikmati hidup, dan beberapa tindakan positif lainnya seperti berjualan, berkumpul, beribadah, dan tetap menolong sesama yang lebih membutuhkan pertolongan.
\end{abstract}

Kata kunci: Rasa Syukur; Pekerja Harian Pariwisata; Covid-19

\begin{abstract}
The purpose of this study is to describe the gratitude of daily workers in the tourism sector during the Covid-19 pandemic. This study uses a descriptive qualitative research method with the technique of taking research subjects using a snowball. The number of research subjects as many as four people who work as tour guides and travel drivers. The data collection in this research was done by using interview, observation, and documentation techniques. From the results of the study, it was found that the gratitude possessed by daily workers in the tourism sector, both transpersonal and personally, came from spiritual and professional support so that they were able to survive during the Covid-19 pandemic. Expressions of gratitude for daily workers in the tourism sector during the Covid-19 pandemic can be seen through appreciation for the income they earn every day, as well as positive feelings such as being happy and enjoying life, and several other positive actions such as selling, gathering, worshiping, and continuing to help others who need help.
\end{abstract}

Keywords: Gratitude; Dailly Workers Tourism; Covid-19

How to Cite: Barus, D.A., Epifania, M.L. (2021). Rasa Syukur Pekerja Harian Sektor Pariwisata pada Masa Pandemi Covid-19. Analitika: Jurnal Magister Psikologi UMA, 13 (2): 156 - 164. 
Debi Angelina Br Barus \& Epifania Margareta Ladapase,

Rasa Syukur Pekerja Harian Sektor Pariwisata pada Masa Pandemi Covid-19

\section{PENDAHULUAN}

Pandemi Covid-19 memberikan dampak yang buruk bagi para pekerja harian di sektor pariwisata seperti tour guide dan supir travel di Kabupaten Sikka. Data statistik pengunjung ke Kabupaten Sikka dalam 5 tahun terakhir (2015 - 2019) menunjukkan peningkatan yang signifikan tinggi, baik wisatawan manca negara maupun lokal, yang memberikan pemasukan yang besar bagi pekerja harian sektor pariwisata. Pekerja harian sektor pariwisata merupakan pekerja yang menggantungkan kehidupannya pada pekerjaan satu hari saja seperti kepada para wisatawan yang datang ke Kabupaten Sikka. Artinya, pekerja ini mendapatkan keuntungan atas apa yang dikerjakan satu hari berdasarkan prestasi kerja satu hari. Semakin banyak wisatawan yang datang, semakin tinggi pula income yang didapatkan oleh pekerja harian. Wisatawan menjadi kunci keberhasilan dari pekerja harian.

Menurut hasil wawancara terhadap lima orang pekerja harian yang ada di Kabupaten Sikka, diketahui bahwa penghasilan yang didapatkan para pekerja harian sebelum pandemi Covid-19 bisa memenuhi kebutuhan hidup mereka sehari-hari, termasuk membiayai sekolah anak. Namun, setelah corona virus menyebar di seluruh nusantara dan dunia, termasuk di Kabupaten Sikka, kondisi tersebut berubah cukup signifikan. Jumlah wisatawan yang datang ke Kabupaten Sikka turun drastis hingga 80\%. Hal ini memberikan dampak negatif pada perilaku pekerja harian seperti stres, emosi tidak stabil dan bahkan melakukan perbuatan negatif sebagai alternatif mencari income dengan cara berjudi. Dampak negatif dari pandemi Covid-19 sangat dirasakan oleh pekerja harian pada sektor pariwisata di kabupaten Sikka.

Kelima pekerja harian yang diwawancari menyebutkan bahwa setelah masa transisi dari pembatasan sosial berskala besar (PSBB) yang dianjurkan oleh pemerintah tetap merasakan seperti putus harapan karena pengunjung ke Kabupaten Sikka tidak menunjukkan peningkatan yang baik. Pekerja harian ini juga menjelaskan bahwa keberlangsungan kehidupan mereka berdasarkan pada banyak atau tidaknya pengunjung yang datang ke Kabupaten Sikka. Pergerakan aktivitas yang dibatasi, penurunan income dan kebutuhan hidup yang harus dipenuhi setiap harinya pada pekerja harian yang membuat perubahan perilaku ke arah negatif, seperti cemas yang berlebihan yang berujung pada stres dan melakukan judi yang kerap terlihat rendahnya rasa syukur yang dimiliki pekerja harian.

Menurut Peterson dan Seligman (2004), salah satu cara untuk bangkit dari keterpurukan adalah melalui sikap syukur. Listiyandini, Nadya, Sonia dan Nathania (2015) menyatakan bahwa bersyukur dapat membantu seseorang untuk meningkatkan kemampuan dirinya dalam menghadapi masalah. Rasa syukur membuat individu memandang rasa sakit atau tekanan hidup yang dialami sebagai sumber pelajaran hidup yang berharga, serta meningkatkan kemampuan coping yang bisa mendorong munculnya pemaknaan diri yang lebih positif.

Menurut Lopez dan Snyder (2003), rasa syukur atau gratitude berasal dari bahasa Latin gratia yang berarti grace atau gratefulness. Sedangkan, menurut Emmons (2007), gratia selalu berhubungan dengan kebaikan, kemurahan hati, dan keindahan 
baik memberi maupun menerima. Syukur memiliki kekuatan untuk menyembuhkan, memberi energi, dan mengubah kehidupan dengan meningkatkan orang secara psikologis, spiritual, fisik, dan kognitif. Dalam istilah psikologi, kebersyukuran merupakan padanan arti dari gratitude. Menurut Isa (dalam Hambali, Meiza \& Fahmi, 2015) definisi syukur adalah kebahagiaan hati atas nikmat yang diperoleh yang diikuti dengan pengarahan seluruh anggota tubuh supaya taat kepada Sang Pemberi nikmat serta pengakuan atas segala nikmat yang diberiNya dengan rendah hati.

Rasa syukur merupakan salah satu faktor yanga sangat berperan penting dalam menciptkan suasana hati yang tenang dan bahagia yang memiliki emosi yang positif dan perilaku sosial yang adaptif (Lenser \& Fincham dalam Mubarak, 2017). Seseorang yang memiliki rasa syukur dalam dirinya akan mampu beradaptasi dan bertahan dalam situasi yang menekan karena mereka memilik respon yang postif dalam menjalankan kehidupan yang penuh tekanan. Menurut Emmons dan McCullough (dalam Mubarak, 2017) rasa syukur merupakan emosi dasar yang dibutuhkan untuk stabilitas kehidupan seseorang. Mengungkapkan rasa syukur kepada Tuhan maupun kepada manusia atas segala sesuatu yang terjadi dalam hidup. Emmons dan Mishra (2011) mengemukakan bahwa rasa syukur mengerakan individu untuk melakukan coping terhadap situasi yang menimbulkan tekanan, salah satunya menghadapi dan menjalankan hidup di masa pandemi covid-19. Maka dapat dikatakan bahwa rasa syukur merupakan bagian dari emosi seseorang secara positif dalam menyikapi suatu peristiwa atau kejadian yang baik maupun yang buruk.

Menurut Mc Cullough, Emmons, dan Tsang (2002) terdapat empat aspek rasa syukur yaitu; 1) Intesity yaitu perilaku seseorang yang bersyukur atas kejadian yang positif; 2) Frequency yaitu individu yang sering bersyukur; 3) Span yaitu merasa bersyukur dalam segala hal; 4) Density yaitu individu yang sering memiliki rasa syukur terhadap orang lain. Peterson dan Seligman (2004) mengungkapkan bahwa rasa syukur memiliki dua aspek yaitu Transpersonal, merupakan rasa syukur yang diberikan kepada Tuhan atau alam semesta atau ungkapan rasa terima kasih diberikan kepada Tuhan yang memiliki kekuatan lebih besar dari dirinya atau alam semesta. Bentuk rasa syukur transpersonal dapat berupa pengalaman yang bersifat spritual dan Personal, merupakan rasa syukur kepada orang lain yang sudah memberikan suatu kebaikan atau keuntungan kepada si penerima atau diri sendiri.

Menurut Fitzgerald (dalam Emmons \& McCullough, 2012) komponen rasa syukur meliputi; 1) Penghargaan yang hangat terhadap seseorang atau suatu kejadian; 2) Niat baik dalam diri; 3) Perilaku yang merupakan implikasi dari penghargaan dan niat baik kepada seseorang ataupun suatu kejadian. Sedangkan menurut Listiyandini, Nadya, Sonia dan Nathania (2015) mengemukakan bahwa rasa syukur memiliki tiga komponen yaitu; 1) Memiliki rasa apresiasi terhadap Tuhan ataupun orang lain dan kehidupan; 2) Perasaan positif terhadap kehidupan yang dimiliki, yaitu di mana seseorang tidak merasa kekurangan dalam hidupnya, selalu merasa berkecukupan terhadap apa yang 
Debi Angelina Br Barus \& Epifania Margareta Ladapase,

dimiliki dan puas terhadap kehidupan yang dijalaninnya; 3) Kecenderungan untuk bertindak positif sebagai ekspresi dari perasaan positif dan apresiasi yang dimiliki.

Pekerja harian sektor pariwisata mendapatkan dampak secara langsung pada masa covid-19, khususnya dalam aspek pendapatan secara ekonomi, hal ini disebabkan karena pekerja harian tidak mendapatkan pendapatan secara pasti. Menurut UndangUndang Nomor 13 Tahun 2003 (dalam Dongoran dkk, 2016) tentang Ketenagakerjaan, pekerja harian adalah setiap orang yang mampu melakukan pekerjaan guna menghasilkan barang dan atau jasa, baik untuk memenuhi kebutuhan sendiri maupun masyrakat. Menurut Soepomo (dalam Hidayah dkk, 2016), pekerja harian adalah semua orang yang menurut hukum (Yurdis) mampu melakukan pekerjaan, baik bekerja kepada orang lain maupun pada suatu badan dengan menerima upah harian. Dengan demikian, peneliti dapat menyimpulkan bahwa pekerja harian adalah orang yang bekerja dengan orang lain atau secara pribadi yang mendapatkan upah harian. Menurut Simatupang dan Andika (2021) menjelaskan pandemic Covid membuat banyak aktivitas bekerja menjadi berubah ke sistem online, yang tentunya sistem pekerjaan ini tidak berlaku pada pekerja harian di sektor pariwisata.

Banyaknya pekerja harian yang kehilangan pekerjaan di Kabupaten Sikka, khususnya pekerja di sektor pariwisata, membuat peneliti tertarik untuk melakukan penelitian. Dan masalah yang menjadi fokus penelitian adalah rasa syukur para pekerja harian selama pandemi Covid-19. Hal ini sangat menarik, karena dengan rasa syukur, para pekerja harian dapat bertahan hidup hingga sekarang, walaupun berada pada tekanan yang tinggi dalam kurun waktu yang tidak bisa ditentukan. Selain itu belum ada penelitian terkait rasa syukur pekerja harian sektor pariwisata pada masa pandemi covid-19, sehingga penelitian ini dapat dikatakan baru dan penting untuk diteliti. Tujuan dari penelitian ini adalah untuk melihat gambaran rasa syukur yang dimiliki oleh pekerja harian sektor pariwisata pada masa pandemi covid-19.

\section{METODE PENELITIAN}

Metode penelitian ini menggunakan metode kualitatif deskriptif. Subjek penelitian atau informan dalam penelitian ini adalah pekerja harian sektor pariwisata yang berjumlah empat orang dan berprofesi sebagai supir travel dan tour guide yang berada di Kabupaten Sikka Nusa Tenggara Timur. Data subjek penelitian/narasumber penelitian ini, adalah sebagai berikut :

Tabel 1

Identitas Narasumber

\begin{tabular}{cccc}
\hline No. & Nama & Usia & Status \\
\hline 1 & IG & 50 & Menikah \\
2 & AG & 59 & Menikah \\
3 & KR & 55 & Menikah \\
4 & NK & 28 & Lajang \\
\hline
\end{tabular}

Teknik pengumpulan data daam penelitian ini dengan menggunakan observasi, wawancara dan dokumentasi. Analisis data penelitian kualitatif dilakukan sepanjang 
penelitian berlangsung sampai data dikatakan jenuh lalu dilakukan triangulasi, coding, kategori sesuai tema-tema yang ingin diteliti oleh peneliti sampai dengan tahap pengambilan kesimpulan.

\section{HASIL DAN PEMBAHASAN}

Berdasarkan hasil penelitian, didapatkan beberapa temuan bahwa setiap narasumber memiliki rasa syukur dan cara mengekspresikan rasa syukur dengan cara yang berbeda-beda. Ada beberapa subjek yang memiliki rasa apresiasi (sense of appreciation) yang sangat tinggi secara transpersonal dan sangat rendah secara personal. Dari empat subjek penelitian tersebut, terdapat dua subjek yaitu IG dan NK yang rasa apresiasi (sense of appreciation)-nya secara transpersonal cenderung lebih rendah dibandingkan secara personal. Hal ini karena kedua subjek mendapatkan kesenangan, ketenangan lebih dari keluarga dan kerabat dekat. Meskipun tidak bisa dipungkiri, mereka juga menyadari bahwa segala sesuatu yang dia peroleh hingga saat ini merupakan pemberian Tuhan dan mereka mensyukuri hal tersebut. Sedangkan dua subjek lainnya lebih tinggi secara transpersonal. AG dan KR lebih memperlihatkan rasa syukur mereka kepada Tuhan dan alam. Bahwa segala sesuatu yang terjadi tidak terlepas dari campur tangan Tuhan Yang Maha Esa. Segala rejeki, nafas, kesusahan dan kesulitan tidak terlepas dari rancangan Tuhan. Tuhan memberi segala kesenangan dan keindahan dalam hidup serta masalah agar kita dapat belajar dari perjalanan dan pengalaman hidup. Bahwa sejatinya segala sumber kebaikan itu ialah milik Tuhan.

Sejalan dengan pernyataan tersebut, Gouldner dan Travis (dalam Bono, Krakauer \& Froh, 2017) menyatakan bahwa syukur akan mendorong individu untuk saling memberikan kebaikan secara timbal balik. Tidak terlepas dari rasa apresiasi diatas, para subjek juga memiliki perasaan positif. Perasaan positif ini lebih terlihat pada transpersonal ke-empat subjek penelitian. Masing-masing mengungkapkan kepuasan terhadap hidupnya serta merasa bahagia dengan dirinya. Mereka bahagia dengan pencapaian dan apa yang mereka peroleh serta yang mereka jalani saat ini. Hasil penelitian Maulidah (2016) menemukan bahwa kebersyukuran memiliki pengaruh positif dan signifikan terhadap kebermaknaan hidup, dengan artian kebersyukuran memberikan dampak positif dalam memaknai hidup.

Tindakan positif yang dilakukan para subjek sebagai wujud nyata dari kebersyukuran ini berbeda-beda. Misalnya pada subjek IG yang lebih cenderung melakukan tindakan positif secara personal. Dimana ia mengisi keseharian di tengah pandemi covid-19 dengan melakukan kegiatan-kegiatan positif seperti membaca, menulis serta menggambar pada botol-botol bekas yang ada. Selain IG, subjek NK juga melakukan kegiatan-kegiatan positif untuk mengembangkan kemampuannya sebagai seorang tour guide. Hal ini seperti mengikuti kursus bahasa, membaca dan mencari tahu hal-hal baru yang belum ia ketahui. Sedangkan pada subjek AG dan KR, mereka lebih mengekspresikan rasa kebersyukurannya dengan lebih mendekatkan diri pada sang Pencipta serta melakukan hal-hal baik. Hal-hal baik di sini dalam arti menolong sesama 
Debi Angelina Br Barus \& Epifania Margareta Ladapase,

Rasa Syukur Pekerja Harian Sektor Pariwisata pada Masa Pandemi Covid-19

yang kesulitan. Meskipun di tengah keterpurukan ekonomi mereka masih bisa sedikit memberikan hal positif terhadap orang lain di sekitar mereka. Schimmel (dalam Simatupang, 2019) menjelaskan bahwa kebahagiaan merupakan penilaian individu terhadap keseluruhan kualitas hidupnya. Ini sesuai dengan pendapat Aquinas (dalam Emmons \& McCullough, 2004) yang mengemukakan bahwa syukur merupakan motivator dari perilaku altruistik, sebab syukur ditandai dengan penghargaan kepada sesuatu yang diberikan orang lain dan menghasilkan respon yang sesuai pula. Hal ini akan mengarahkan pada perilaku altruistik.

Masa pandemi Covid-19 banyak memberikan tekanan hidup bagi semua orang, khususnya bagi pekerja harian sektor pariwisata. Hal ini terjadi karena pada masa pandemi Covid-19, banyak negara menutup dan membatasi aktivitas penduduk, khusunya aktivitas berwisata. Kondisi tersebut membuat pendapatan pekerja harian sektor pariwisata di Kabupaten Sikka mengalami penurunan drastis, bahkan sebagian pekerja harian tidak memperoleh pendapatan sama sekali dalam sehari karena tidak memiliki pekerjaan selama pandemi Covid-19. Selain tekanan secara finasial, tekanan secara sosial juga dilami oleh pekerja harian sektor pariwisata, khususnya tour guide dan supir travel. Mereka yang terbiasa berpergian dan bertemu dengan orang baru ini, masa pandemi Covid-19 seperti saat ini mengalami perubahan hidup yang sangat berbeda dari hari-hari sebelumnya. Kondisi tersebut membuat mereka merasa tertekan dan stres.

Saat mewawancara keempat narasumber, mereka mengukapkan bahwa pada awal pandemi Covid-19 masuk Kabupaten Sikka, mereka mengalami stres. Hal ini ditandai dengan gejala sulit tidur, emosi tidak terkontrol, dan mengomsumsi minuman keras. Mereka tidak tahu mau berbuat apa untuk mendapatkan penghasilan guna mencukupi kebutuhan keluarga sehari-hari. Kondisi terpuruk dialami oleh keempat narasumber dalam kurun waktu kurang lebih enam bulan. Namun, setelah mengalami kondisi itu, mereka mulai bangkit lagi untuk menata hudup menjadi lebih baik. Salah satu faktor yang mendorong keempat narasumber untuk bangkit dari keterpurukan adalah memiliki rasa syukur. Keempat narasumber merasa sangat bersyukur di masa pandemi covid-19, karena pada masa yang sulit ini mereka mendapatkan pemahaman yang baru dan positif dalam menjalankan hidup. Menurut Rachmadi, Safitri dan Aini (2019) kebersyukuran adalah topik yang telah dibahas sejak lama dalam bidang keilmuan filosofi dan teologi. Menurut Emmons (dalam Haryanto dan Kertamuda, 2016) rasa syukur merupakan bentuk rasa takjub dan berterimakasih atas manfaat yang didapat dalam suatu keadaan.

Aspek Rasa syukur yang dimiliki oleh keempat nasarasumber ini berbeda-beda. Dari hasil penelitian, ditemukan bahwa narsumber KR sangat bersyukur dalam aspek traspersonal. KR mengungkapkan bahwa masa pandemi Covid-19 membawa KR lebih dekat kepada Tuhan dan bersyukur atas segala sesuatu yang sudah Tuhan berikan dalam hidup KR dan keluaraga. Watkins Woodward, Stone dan Kolts (2003) menyatakan bahwa rasa syukur merupakan suatu sikap menghargai hidup sebagai karunia dan patut untuk mengungkapkan penghargaan terhadap karunia yang 
diberikan. KR menunjukkan rasa syukurnya dengan cara mengingat kembali apa yang sudah Tuhan berikan dalam hidup KR dan keluarga. Mengingat kembali setiap kebaikan yang diterima merupakan bagian dari sense of appreciation atau penghargaan yang hangat terhadap seseorang atau sesuatu (Emmons \& McCullough, 2012).

KR juga merasa sangat bersyukur atas adanya pandemi Covid-19 ini, karena pada masa yang sukar ini, KR memiliki pola hidup yang lebih baik. KR mulai mengisi hidupnya dengan melakukan kegitan rohani seperti rajin berdoa dan berkumpul bersama keluarga. KR juga mulai mencari alternatif pekerjaan lain untuk dapat mencukupi kebutuhan keluarga. Penelitian Froh, Yurkewicz dan Kashdan (2009) mengungkapkan bahwa rasa syukur dapat terlihat melalui adanya penghargaan terhadap diri, memiliki pandangan hidup yang positif, dan memiliki inisiatif.

Sedangkan, ketiga narasumber lainya memiliki rasa syukur secara personal. Ketiga narasumber tersebut merasa bersyukur pada masa pandemi Covid-19 ini karena mereka mendapatkan dukungan dari keluarga dan kerabat terdekat, serta dukungan secara finasial dari tamu-tamu yang pernah mereka layani. Narasumber IG mengatakan bahwa selama pandemi Covid-19, ia mendapatkan dukungan dari istri, anak-anak, dan teman seprofesi. Hal ini didukung oleh penelitian Simatupang (2017) yang menemukan bahwa dukungan keluarga sangat berpengaruh terhadap keharmonisan dalam keluarga, khususnya ketika anggota keluarga berada dalam masa sulit. IG merasa sangat bersyukur karena pada masa pandemi Covid-19 ini ia semakin dekat dengan keluarga, sering menghabiskan waktu bersama istri dan melakukan kegiatan yang positif seperti melukis dan menanam bunga. IG juga mengaku mulai memiliki pola hidup yang sehat, di mana selama pandemi Covid-19, ia memiliki jam tidur yang lebih banyak. IG juga bersyukur karena pada masa pandemi Covid-19 ini ia tidak mengalami kekurangan secara finansial karena ada istri yang membantu. Menurut Emmons \& McCullough (2004) rasa syukur membuat seseorang lebih bijaknasana dalam menyikapi lingkungan dan hidupnya.

Beda halnya dengan narasumber AG, pada awal masa pandemi Covid-19 AG mengalami stres yang cukup berat. Namun, AG bisa bangkit kembali setelah terpuruk selama kurang lebih enam bulan. AG merasa bersyukur secara transpersonal dan personal, karena pada masa sulit ini AG masih bisa menikmati alam yang begitu indah dan mendapatkan banyak dukungan dari teman seprofesi. AG memiliki perasaan bahagia dan puas atas apa yang sudah AG capai selama berprofesi sebagai tour guide. AG tidak pernah merasa menyesal atas profesi yang ia geluti selama bertahun-tahun. AG juga bersyukur karaena pada masa pandemi Covid-19 ini AG terpilih menjadi Ketua HPI (Himpunan Pramuwisata Indonesia) Kabupaten Sikka. Rasa sykurur yang dimiliki AG terlihat dari tindakan postif yang dilakukaan AG dengan cara membantu teman seprofesi yang mengalami kesusahan secara finasial. Walaupun AG memngalami penurunan pendapatan, namun ia tetap dapat membantu teman yang mengalami kesusahan secara finasial. Tindakan tersebut dilakukan AG sebagai bentuk rasa syukur AG atas apa yang selama ini ia terima. AG mengaku patut mengungkapak rasa syukurnya dengan cara 
berbagi kepada sesama yang membutuhkan. Kondisi yang dirasakan AG sesuai dengan penelitian Mukhlis dan Koentjoro (2015) yang menyatakan bahwa kebersyukuran mampu menurunkan kecemasan pada individu.

Tindakan positif tersebut juga dimiliki oleh narasumber NK. Ia mengungkapkan rasa syukurnya dengan cara membantu teman seprofesi yang membutuhkan pertolongan. NK memiliki rasa syukur pada masa pandemi Covid-19 ini kerana pada masa yang sulit ini, NK justru dapat menikmati kebersamaan dengan keluarga dan teman seprofesi yang selama ini jarang ia rasakan. Selain itu, NK juga sangat bersyukur karena pada masa pandemi Covid-19 ini, NK banyak mendapatkan teman seprofesi di bidang pariwisata, dan dari mereka, NK mendapatkan banyak pengalaman dan pengetahuan baru yang membuka wawasannya, yang kelak dapat menunjang karir NK di bidang pariwisata.

\section{SIMPULAN}

Rasa syukur pekerja harian sektor pariwisata di tengah pandemi covid-19 sangat relatif. Tergantung pribadi masing-masing memaknai arti sebuah kehidupan. Pandemi yang terjadi saat ini mengharuskan setiap individu untuk mampu memiliki rasa syukur sehingga individu mampu bertahan. Rasa syukur juga dapat diterima dari luar diri seperti dukungan keluarga, sosial dan pasangan yang mampu menguatkan individu dalam menghadapi situasi yang terjadi.

Memberikan dukungan terhadap teman khususnya teman seprofesi dapat berdampak positif pada individu. Peningkatan rasa syukur juga mampu diperkuat melalui berdoa dan berkumpul bersama keluarga sehingga fokus individu pada hal-hal positif. Di saat pandemi juga diperlukan lebih kreatif seperti membuka usaha sehingga individu mampu menghadapi dan menjalani jalur lain selain profesi yang dilakukan saat ini sehingga menambah pendapatan keluarga di masa yang sulit ini.

Saran yang perlu dipertimbangkan setelah penelitian ini dilaksanakan adalah: Bagi subjek penelitian agar meningkatkan keterampilan di sektor lain, sehingga ketika terjadi bencana seperti pandemi covid-19, pekerja harian bisa mencari alternatif pekerjaan yang lain untuk memenuhi kebutuhan keluarga. Bagi Dinas Pariwisata, agar memperhatikan kesejahteraan pekerja harian sektor pariwisata, dengan cara memberikan pelatihan atau penyuluhan guna meningkatkan kapasitas sumber daya manusia. Bagi gereja, agar lebih gencar membuat kegiatan kerohanian di tengah kehidupan Jemaat yang penuh tekanan.

\section{DAFTAR PUSTAKA}

Dongoran, F. R., Nisa, K., Sihombing, M., \& Purbs, L. D. (2016). Analisis jumlah pengangguran dan ketenagakerjaan terhadap keberadaan usaha mikro kecil dan menengah di kota Medan. Jurnal EduTech. Vol. 2, No.2. Hal.59-72.

Emmons, R. (2007). Thanks How To New Science Of Gratitude Can Make You Happier [foxit Reader PDF Version 6.o]. Retrived from http://gen.lib.rus.ec/book/indexd.php.

Emmons, R.A., \& Mishra, A. (2011). Why Gratitude Enhances Well-Being: What We Know, What We Need To Know. In K.M.Sheldon, T.B. Kashdan, \& M. E Steger (Eds), Designing positive psychology: Taking stock and moving forward (pp.248-262) 
Emmons, R.A., \& Mc Cullough, M.E. (2012). The Pschology Of Gratitude. Oxford, New York: Oxford University Press.

Froh, J.J., Kashdan, TB., Ozimkowski, KM., \& Miller, N. (2009). Who Benefits The Most From Gratitude Intervention In Children And Adolescence? Examining Positive Affect As A Moderator. The journal of positive Psyhology,4, 408-422.

Hambali, A., Meiza, A., \& Fahmi, I. (2015). Faktor-faktor yang berperan dalam kebersyukuran (gratitude) pada orangtua anak berkebutuhan khusus perspektif psikologi Islam. Psympathic, Jurnal Ilmiah Psikologi, Vol. 2, No. 1, 94-101.

Haryanto, Hendrik,. Chris \& Kertamuda, F.E. (2016). Syukur sebagai Sebuak Pemaknaan.Jurnal Insight. Vol.18.No.2.Hal:2548-180o.

Hidayah, Wahyu; Militina, Theresia \& Ulfah, Yana. (2016). Faktor-Faktor Yang Mempengaruhi Tenaga Kerja Dan Produk Domestik Regional Bruto Di Kota Samarinda. Universitas Mulawarma Indonesia. Jurnal Ekonomi Keuangan, dan Manajemen. Vol. 12. No. 1, Hal. 138-162.

Listiyandini, R.A., Nadya, R., Sonia, L., \& Nathania, A. (2015). Mengukur Rasa Syukur: Pengembangan Model Awal Skala Bersyukur Versi Indonesia. Jurnal Psikologi Ulayat.Vol:2.No.2, hal.473-496.

Lopeez, S.J., \& snyder, C.R. (2003). Positive psychological assessment: a handbook of models and measures. Washington. DC: american Psychological Association.

Maulidah, I. L. (2016). Kebersyukuran dan kebermaknaan hidup pada penderita jantung koroner. Psycho Idea, Vol. 14, No. 2, 10-16.

Mukhlis, H., Koentjoro. (2015). Pelatihan kebersyukuran untuk menurunkan kecemasan menghadapi ujian nasional pada siswa SMA. Gadjah Mada Journal of Professional Psychology, Vol. 1, No. 3, 203215 .

McCullough, M. E., Emmons, R.A., \& Tsang, J. (2002). The Greteful Disposition: A Conceptual And Empirical Topography. Journal of Personality and Social Psychology. 82, 112-127.

Mubarak. Umi.(2017). Korelasi Antara Kebersyukuran Terhadap Kecemasan Menghadapi Persalinan Pada Ibu Hamil Trimester Tiga Di Banjarmasin. Jurnal Psikologi. Vol:13. No:1, Hal.73-79.

Peterson, C., \& Seligman, M. E. P. (2004). Character Strengths And Virtues: A Handbook For Classification. Washington, DC: American Psychological Association.

Rachmadi, A. G., Safitri, N., \& Aini, T. Q. (2019). Kebersyukuran: Studi komparasiperspektif psikologi Barat dan psikologi Islam. Psikologika: Jurnal Pemikiran dan Penelitian Psikologi, Vol. 24, No. 2, 115128.

Simatupang, M. (2019). Gambaran keharmonisan keluarga commuter family pada anggota brigade mobile kepolisian daerah Sumatera Utara. Analitika: Jurnal Magister Psikologi UMA, Vol 9, No. 1, 27-35.

Simatupang, M. (2019). Kebahagiaan pada wanita Plari Depo (Studi kualitatif deskriptif di Kabupaten Sikka Nusa Tenggara Timur). Psychopedia Jurnal Psikologi Universitas Buana Perjuangan Karawang, Vol. 4, No. 1, 37-46.

Simatupang, M., Andika, R. (2021). Persepsi karyawan terkait work from home. Prosiding Konferensi Hasil Penelitian dan Dosen, 70-82.

Watkins, P. C,. Woodward, K., Stone, T., \& Kolts, R. L. (2003). Gratitude And Hapiness. Development Of A Measure Of Gratitude, And Relationship With Subjektive Well-Being. Social Bahavior and Personality: an International Journal, 31(5): 43-452 